\title{
Antioxidant, anti-inflammatory and antimicrobial activities of methanolic and aqueous extract of the leaves of Pistacia lentiscus $\mathbf{L}$.
}

Nouioua Wafa ${ }^{1 *}$ and Gaamoune Sofiane ${ }^{2}$

${ }^{*}$ Laboratory of Phytotherapy Applied to Chronic Diseases, Faculty of Natural Life and Sciences, University Ferbat Abbas Setif, Algeria, El Ber, Sétif 19000.

${ }^{2}$ National Institute of Agricultural Research -Setif-Algeria, INRAA, BP 80, route des fermes, Sétif

Corresponding author email: noniona.wafa@yahoo.fr

Key words: Antioxidant activity, mastic, antibacterial activity, anti-inflammatory activity.

Publication date 29/02/2020, http://m.elewa.org/Journals/about-japs/

\section{$1 \quad$ ABSTRACT}

In this study, The Montaigne of Boutaleb contains a plant heritage characterized by the presence of several species that possess medicinal properties. The methanolic and aqueous extract of the leaves of Pistacia lentiscus were prepared, the yield of the methanolic extract was $2.99 \mathrm{~g}$ the percentages $37.2 \%$ and the yield of the aqueous extract is $0.98 \mathrm{~g}$ with percentages $19.6 \%$. The total dosage of polyphenols and flavonoids in the methanol extract was $38.27 \pm 6.30 \mathrm{mg}$ EAG/g extract and $9.80 \pm 0,160, \mathrm{mg}$ EAG/g extract, respectively. The total dosage of polyphenols and flavonoids in the aqueous extract was $26.76 \pm 2.47 \mathrm{mg}$ EAG/g extract and 4, 15 $\pm 0.09 \mathrm{mg}$ EAG/g extract, respectively. The effect of aqueous and methanolic extracts of mastic leaves were evaluated using the DPPH test. Both extracts have shown a weak trapping effect towards the free radicals with an $\mathrm{IC}_{50} 68.27 \pm 9.96 \mu \mathrm{g} / \mathrm{ml}$ and with an $\mathrm{IC}_{50} 72.92 \pm 9.43 \mu \mathrm{g} / \mathrm{ml}$ respectively, then weak activity antioxidant .The antibacterial activity of the methanolic and aqueous extract of the leaves of Pistacia lentiscus is significant. The aqueous and methanolic extract of mastic leaves possess a very strong anti-inflammatory activity to protect the membrane of human blood red blood cells.

\section{INTRODUCTION}

Plants constitute an important source of active natural products, which differ widely in terms of structure and biological properties. They have a remarkable role in traditional medicine in different countries (Argolo et al., 2004; Johnson 2001). The Reactive Oxygen Species (ROS) naturally produced in our body are highly reactive molecules responsible for the deterioration of macromolecules in the cell (proteins, lipids, glucides, DNA). Under normal conditions, the damage is controlled by the antioxidant defense system which includes enzymatic (superoxide dismutase, catalase; and glutathione peroxidase), non-enzymatic factors (vitamins: ascorbic acid, tocopherols, carotenoids) and other antioxidant micronutrients present in fruits, vegetables and plant (Rietveld A and Wiseman 2003, Serafini et al.,2003) . Oxidative stress plays a crucial role in the development of age-related diseases including arthritis, diabetes, dementia, cancer, atherosclerosis, vascular diseases, obesity, osteoporosis, and metabolic syndrome (Tan et al., 2018, Abbas et al., 2017, Liu et al ., 2005 ) Inflammation and oxidative stress play an important role in various diseases. Inflammation is an immunological defense mechanism elicited in response to mechanical injuries, burns, microbial infections, allergens, and another noxious stimulus. In the human 
body, inflammation is considered part of the complex biological response to remove injury or harmful stimuli such as pathogens, damaged cells, or irritation. This response leads to many physical symptoms such as pain, fever, and swelling, because of many associated changes such as vasodilation, increased vascular permeability, and plasma extravasation (Yoon and Baek 2005, Winrow et al ., 1996, Gutteridge 1995, Menichini et al ., 2009, Mueller et al ., 2005). Pistacia lenitscus L. is a tree from Ancardiaceae family, which can reach over 15 $\mathrm{m}$ in height and grows in arid and semi-arid

\section{MATERIAL AND METHODS}

3.1 Plant material: The areal parts of $R$. eriocalyx were taken from the massif of Boutaleb (X1 E: $5^{\circ} 30^{\prime} 2.46^{\prime \prime} \mathrm{Y} 1 \mathrm{~N}: 35^{\circ} 44^{\mathrm{ee}} 41.74 " ; \mathrm{X} 2$ $\mathrm{E}: 5^{\circ} 25^{\prime} 17.69^{\prime \prime} \mathrm{Y} 2 \mathrm{~N}: 35^{\circ} 50^{\text {ee }} 1.85^{\prime \prime} ; \mathrm{X} 3 \mathrm{E}: 5^{\circ}$ 8' 35, 98" Y3 N: $35^{\circ} 43^{\text {ee }} 12.47^{\prime \prime}$; X4 E: $5^{\circ} 18^{\prime}$

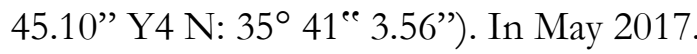

3.2 Preparation of aqueous extracts: The method for preparing aqueous extracts from the dried plant has been already described by Predrag et al., (2005).Briefly, dried plant material (10 g) was stirred in $100 \mathrm{ml}$ of distilled water for $15 \mathrm{~min}$ at $90 \circ \mathrm{C}$ followed by rapid filtration through four layers of gauze and then by a more delicate filtration through Whatman filter paper \#1. The resulting filtrate evaporated to dryness under vacuum. The powder was stored at $-10 \circ \mathrm{C}$ until required.

3.3 Preparation of methanol extract: The areal parts of the two species were powdered and macerated in $80 \%$ methanol for 24, 48 and $72 \mathrm{~h}$, at the laboratory temperature $(1: 10 \mathrm{w} / \mathrm{v}$, $10 \mathrm{~g}$ of dried herb). After maceration, the extracts were collected, filtered and evaporated to dryness under vacuum (Lakić et al., 2010). The dry extracts were stored at a temperature of $-18{ }^{\circ} \mathrm{C}$ for later use.

\subsection{Determination of Total Phenolic} Content: For total polyphenol determination, the Foline Ciocalteu method was used ( $\mathrm{Li}$ et al., 2007). The samples $(0.2 \mathrm{~mL})$ were mixed with 1 $\mathrm{ml}$ of the Folin-Ciocalteu reagent previously diluted with $10 \mathrm{~mL}$ of deionized water. The areas of Algeria, its vernacular name is "Darwo". P. atlantica is valued because it is the source of mastic gum (Bellakhder, 1997). Among 15 known species of pistachios, only some species grow in Algeria, such as Pistacia vera L., Pistacia atlantica Desf, and Pistacia lenitscus L. These have played an important role in folk medicine and have been used in the treatment of eczema, throat infection, renal stone, and asthma. They also act as astringent, antiinflammatory, antipyretic, antibacterial, antiviral, pectoral, and stimulant (Tohidi et al., 2011).

solutions were allowed to stand for $4 \mathrm{~min}$ at 25 ${ }^{\circ} \mathrm{C}$ before $0.2 \mathrm{~mL}$ of a saturated sodium carbonate solution $(75 \mathrm{mg} / \mathrm{mL})$ was added. The mixed solutions were allowed to stand for another $120 \mathrm{~min}$ before the absorbance was measured at $765 \mathrm{~nm}$. Gallic acid was used as a standard for the calibration curve. The total phenolic compounds content was expressed as mg equivalent of Gallic acid per gram of extract (mg EAG/GE).

3.5 Determination of total flavonoids contents: The flavonoids content in our extracts were estimated by the Aluminium chloride solution according to the method described by (Bahorun et al., 1996). Briefly, 1 $\mathrm{mL}$ of the methanol solution of the extracts was added to $1 \mathrm{~mL}$ of $2 \% \mathrm{AlCl}_{3}$ in methanol. After $10 \mathrm{~min}$, the absorbance was determined at $430 \mathrm{~nm}$. Quercetin was used as a standard. Results were expressed as $\mathrm{mg}$ equivalent Quercetin per gram of extract (mg EQ/GE).

3.4 DPPH Assay: The donation capacity of extract was measured by bleaching of the purple-coloured solution of 1, 1-diphenyl-2picrylhydrazyl radical (DPPH) according to the method of (Hanato et al., 1998). One millilitre of the extracts at different concentrations was added to $0.5 \mathrm{~mL}$ of $\mathrm{DPPH}$-methanol solution. The mixtures were shaken vigorously and left standing at the laboratory temperature for 30 min in the dark. The absorbance of the resulting solutions was measured at $517 \mathrm{~nm}$. 
The antiradical activity was expressed as $\mathrm{IC}_{50}$ (micrograms per millilitre). The ability to scavenge the DPPH radical was calculated using the following equation:

DPPH scavenging effect $(\%)=\left[\left(A_{0}-A_{1}\right) / A_{0}\right] \times$ 100

Where:

$\mathrm{A}_{0}$ : the absorbance of the control at $30 \mathrm{~min}$ $A_{1}$ : is the absorbance of the sample at $30 \mathrm{~min}$. Butylated hydroxytoluene (BHT) was used as standard (Bettaie et al., 2011).

3.5 Reducing power: The reducing power was determined according to the method of (Oyaizu 1986). Two and a half (2.5) $\mathrm{mL}$ of the extracts were mixed with $2.5 \mathrm{~mL}$ of sodium phosphate buffer (pH 6.6; $200 \mathrm{mmol} / \mathrm{L}$ ) and $2.5 \mathrm{~mL}$ of potassium ferricyanide $(10 \mathrm{mg} / \mathrm{mL})$. The mixtures were incubated at $50{ }^{\circ} \mathrm{C}$ for $20 \mathrm{~min}$. After cooling, $2.5 \mathrm{~mL}$ of trichloroacetic acid $(100 \mathrm{mg} / \mathrm{mL})$ were added; the mixtures were centrifuged at $200 \mathrm{~g}$ for $10 \mathrm{~min}$. The upper layer $(5 \mathrm{~mL})$ was mixed with $5 \mathrm{~mL}$ of deionized water and $1 \mathrm{~mL}$ of $1 \mathrm{mg} / \mathrm{mL}$ ferric chloride, and the absorbance was measured at $700 \mathrm{~nm}$ against a blank. $\mathrm{EC}_{50}$ value (mg extract $/ \mathrm{mL}$ ) is the effective concentration at which the absorbance was 0.5 for reducing power and was obtained by interpolation from the linear regression analysis. Ascorbic acid was used as a reference standard (Seema et al., 2011).

3.6 The Human Red Blood Cell (HRBC) membrane stabilization method:

To prepare the HRBC suspension, fresh completely human blood $(10 \mathrm{~mL})$ was collected and transferred into the centrifuge tubes. These lasts were centrifuged at $3000 \mathrm{rpm}$ for $10 \mathrm{~min}$ thrice and washed with an equal volume of normal saline each time. The volume of blood was measured and reconstituted as $10 \% \mathrm{v} / \mathrm{v}$ suspension with normal saline.

The principle involved here was stabilization of human red blood cell membrane by hypotonicity induced membrane lysis. The mixtures contain $1 \mathrm{~mL}$ phosphate buffer $(\mathrm{pH} 7.4,0.15$ M), $2 \mathrm{~mL}$ hypo saline (0.36 \%), $0.5 \mathrm{~mL}$ HRBC suspension $(10 \% \mathrm{v} / \mathrm{v})$ and $0.5 \mathrm{~mL}$ of plant extracts or standard drug (diclofenac sodium) at various concentrations $(10,50,100,250,500$ $\mu \mathrm{g} / \mathrm{mL}$ ). The control was distilled water instead of hyposaline to produce $100 \%$ hemolysis.

The mixtures were incubated at $37{ }^{\circ} \mathrm{C}$ for 30 min and centrifuged at $2500 \mathrm{rpm}$ for $5 \mathrm{~min}$. The absorbance of hemoglobin content in the suspensions was estimated at $560 \mathrm{~nm}$. The percentage of hemolysis of HRBC membrane can be calculated as follows:

Haemolysis (\%) $=$ (Optical density of Test sample $/$ Optical density of Control) $\times 100$

However, the percentage of HRBC membrane stabilization can be calculated as follows:

Protection $(\%)=100-[($ Optical density of Test sample / Optical density of Control) $\times 100]$.

3.7 Antimicrobial activity: Bacteria Strains were obtained from the American Type Culture Collection: Gram-positive bacteria (Staphylococcus aureus ATCC25923 and Bacillus subtilis ATCC6633), Gram-negative bacteria (Klebsiella pneumonia ATCC700603) and one yeast: Candida albicans ATCC1024. Muller Hinton agar was used for bacteria culture and Sabouraud for yeast. ,

3.8 Anti-bacterial Activity: Agar disc diffusion method was employed for the determination of antibacterial activities of the extract (NCCLS1999, NCCLS1 997). Briefly, a suspension of the tested microorganism $\left(10^{8}\right.$ CFU / mL) was spread on the solid media plates. Filter paper discs (6 $\mathrm{mm}$ in diameter) were impregnated with $10 \mu \mathrm{L}(100 \mathrm{mg} / \mathrm{mL})$ of the extract and placed on the inoculated plates. These plates were incubated at $37{ }^{\circ} \mathrm{C}$ for 24 hours. Gentamicin $(10 \mu \mathrm{g} /$ disc) was used as a standard and dimethylsulfoxide DMSO as a control. The antibacterial activity was determined by measuring of inhibition zone diameters ( $\mathrm{mm}$ ) and was evaluated according to the parameters suggested by (Alves et al. 2000):

- $\quad<9 \mathrm{~mm}$, inactive ;

- $\quad$ 9-12 $\mathrm{mm}$, less active ;

- $\quad$ 13-18 mm, active; 
- $\quad>18 \mathrm{~mm}$, very active.

3.9 Statistical analysis: Results were expressed as the mean \pm standard deviation. Data was statistically analysed using one-way ANOVA and Newman-Keuls Multiple

\section{RESULTS AND DISCUSSIONS}

4.1 Performance of extracts: The maceration of $5 \mathrm{~g}$ of the leaves of Pistacia lentiscus L. gave a yield of $0.98 \mathrm{~g}$ of aqueous extract $(19.6 \%)$, which has the appearance of a fine hygroscopic chestnut white powder. Where a maceration of the same amount in methanol
Comparison to determine whether there were any significant with the criterion of $\mathrm{P}$ values $<$ 0.05 between methanol extracts of the two species and standards, using Graphpad prism 5 Demo Software.

gave a yield of $2.99 \mathrm{~g}$ methanolic extract $(59.8 \%)$ of caramel colour. Each extract was characterized by its colour and yield. Total phenolic, flavonoid, and contents of the leaves, of two extract $P$. lentiscus are shown in Table 1

Table. 1: Total polyphenol and flavonoid content of Pistacia lentiscus L. extracts. The values are the average of three tests \pm SD.

\begin{tabular}{|l|l|l|}
\hline Extracts & $\begin{array}{l}\text { Total polyphenol content } \\
\text { mg EAG/g extract }\end{array}$ & $\begin{array}{l}\text { Flavonoid content } \\
\text { mg EQ/g extract }\end{array}$ \\
\hline Extract Aqueous & $26,76 \pm 2,47$ & $4,15 \pm 0,09$ \\
\hline Extract Methanolic & $38,27 \pm 6,30$ & $9,80 \pm 0,16$ \\
\hline
\end{tabular}

It is well known that phenolic compounds contribute to the quality and nutritional value in terms of modifying colour, taste, aroma, and flavour and in providing health beneficial effects. They also serve in plant defense mechanisms to counteract reactive oxygen species (ROS) in order to survive and prevent molecular damage and damage by microorganisms, insects, and herbivores (Vaya et al., 1997).

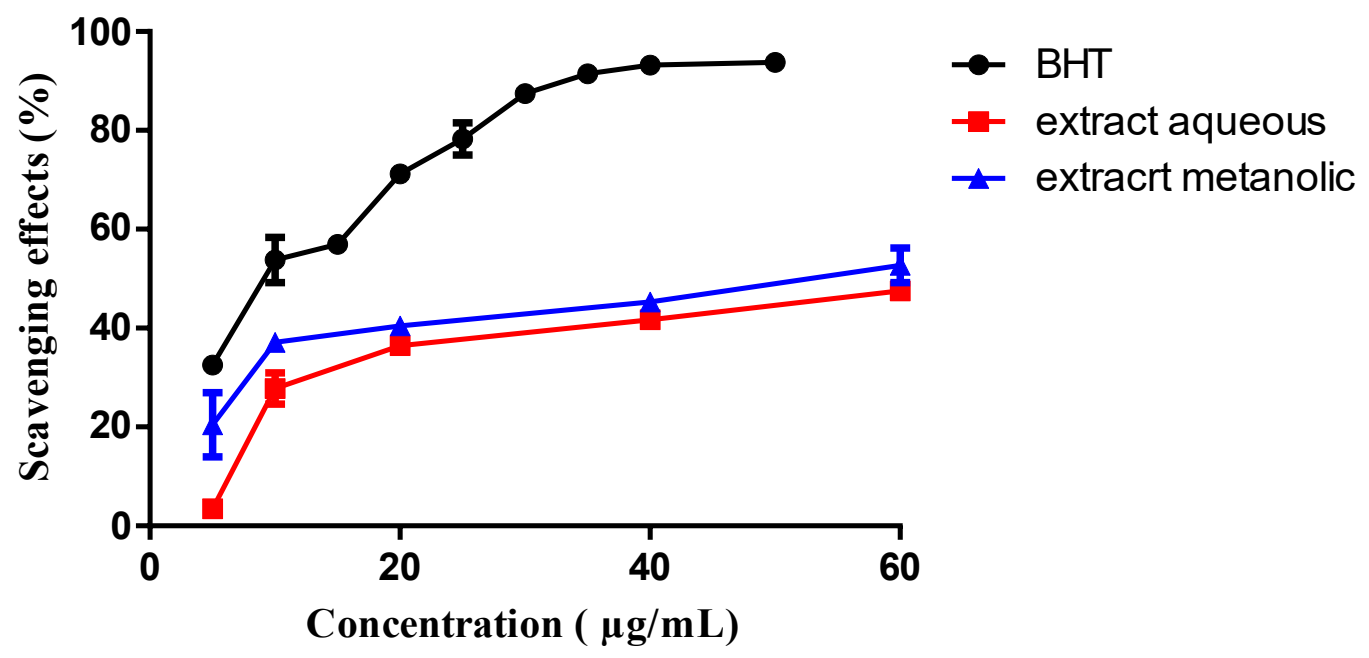

Figure 1: Anti-radical activity of the methanolic extract and the aqueous extract of the leaves of Pistacia lentiscus L. and BHT vis-à-vis the radical DPPH. 
The aqueous and methanolic extract of Pistacia lentiscus L. leaves contains significant amounts of flavonoids and polyphenols, which are known as antioxidants with the ability to trap radical species. The latter two groups have $\mathrm{OH}$ molecules in their structure, responsible for antioxidant activity if for this reason there is a low antioxidant activity of the methanolic extract with $\mathrm{IC}_{50} 68.27 \pm 9.96 \mu \mathrm{g} / \mathrm{ml} * * *$ and the aqueous extract with $\mathrm{IC}_{50} 72.92 \pm 9.43 \mu \mathrm{g} /$ $\mathrm{ml} * * *$ respectively by BHT contribution with $\mathrm{IC}_{50} 8.5 \pm 0.8 \mu \mathrm{g} / \mathrm{ml}$. The results of the aqueous extract of this test, which has low antioxidant activity, are compared with the results of the aqueous extract of the same study done by (Ferradji 2011).which finds the following results $\mathrm{IC}_{50}$ of the aqueous extract of Pistacia lentiscus L. leaves is $51.66 \pm 3.91 \mu \mathrm{g} / \mathrm{ml}$ and BHT with $54.29 \pm 1.99 \mu \mathrm{g} / \mathrm{ml}$, so this antioxidant power is most likely due to the phenolic and flavonoid compounds present in Pistacia lentiscus L. leaves.

4.2 Anti-inflammatory activity: The study of the anti-inflammatory activity, which is based on the effect of the aqueous and methanolic extract of Pistacia lentiscus L. leaves on the membrane of human red blood cells, gives the following results in (fig 2)

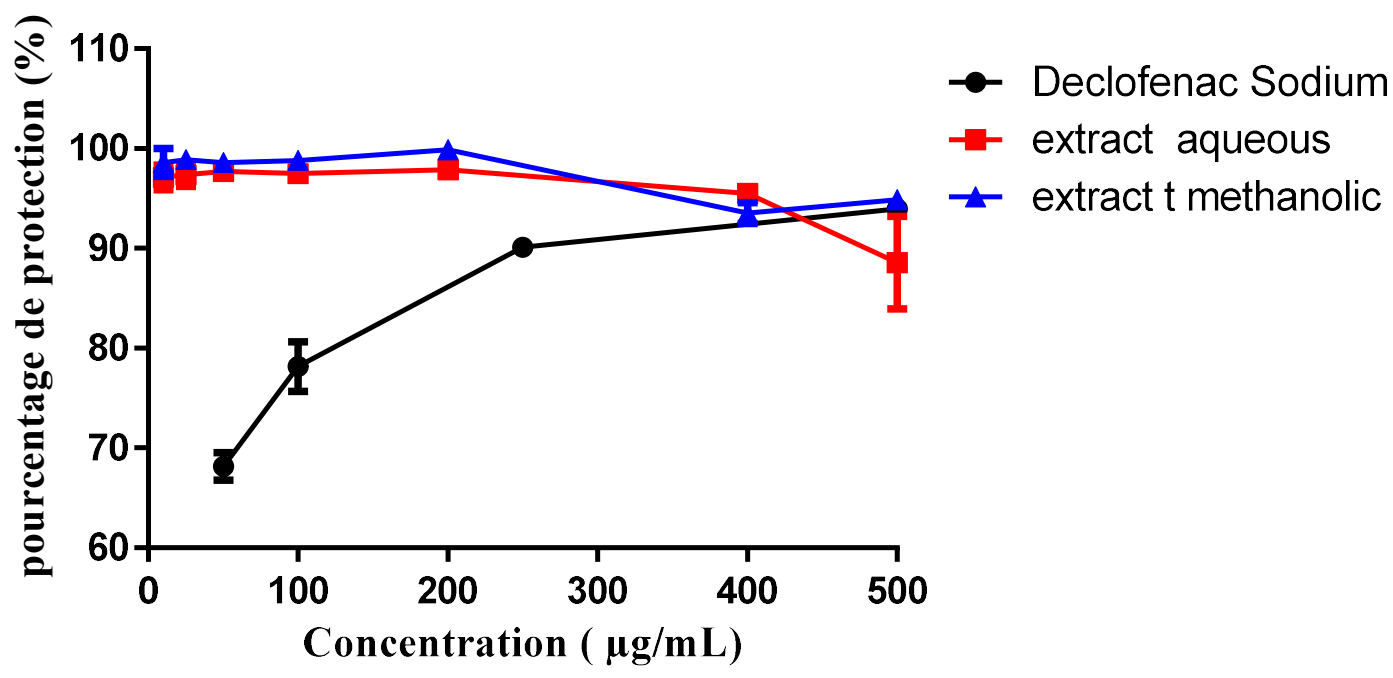

Figure.2: Anti-inflammatory activity of methanolic extract and aqueous extract of leaves of Pistacia lentiscus L. and diclofenac

The aqueous and methanolic extract of the Pistacia lentiscus L. leaves has a beneficial effect on the membrane of human red blood cells, because they allow the protection of this membrane and gives it great resistance without bursting, and without denaturing it by adding diclofenac, i.e. these two extracts have a very strong and very significant anti-inflammatory activity by adding to this "diclofenac" drug. These results qualify these two extracts to have anti-inflammatory properties, against inflammation of the red blood cell membrane and to increase their resistance and protection value.

4.3 Antimicrobial activity: According to figures $(3,4,5)$ it was observed that all bacterial species used in this test have no sensitivity to methanolic extract in the leaves of Pistacia lentiscus L., and the same result that notices it on the aqueous extract ( figures: 6,7,8), while the antibiotic considered a perfect result, Staphylococcus aureus (25.61 \pm 0.19$)$, Bacillus cereus (28.61 \pm 0.06), Pseudomonas aeruginosa (39.30 \pm $0.55)$ (figures: 9,10,11) . 


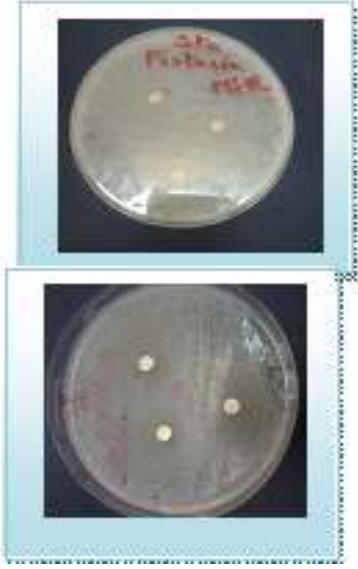

Figure 3: The effect of the methanolic extract on Staphylococcus aureus

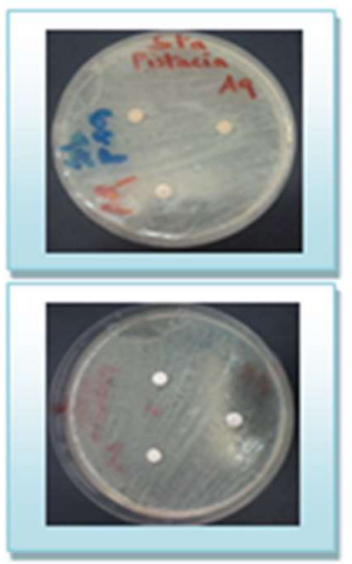

Figure 6: The effect of the aqueous extract onStaphylococcus aureus.

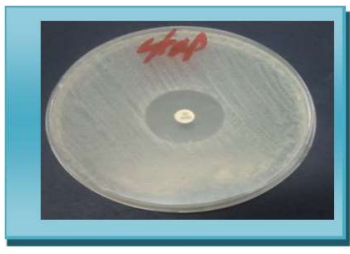

Figure 9: The effect of gentamicin on Staphylococcus aureus.

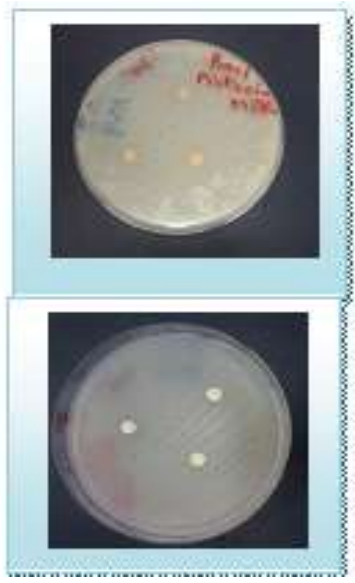

Figure 4: The effect of the methanolic extract on Bacillus cereus

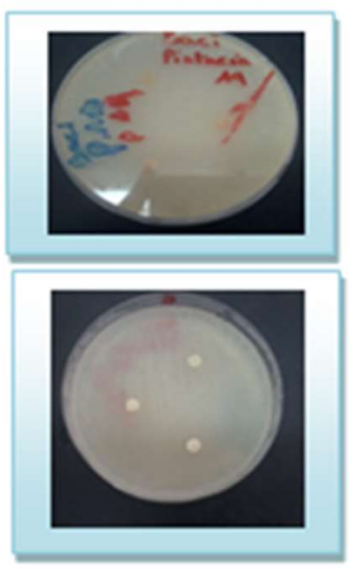

Figure7: The effect of the aqueous extract on Bacillus cereus.

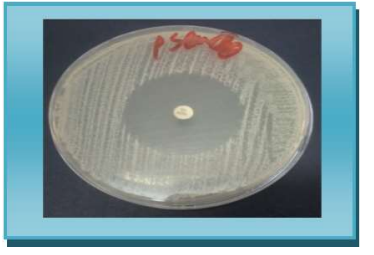

Figure 10: The effect of gentamicin on Bacillus cereus.

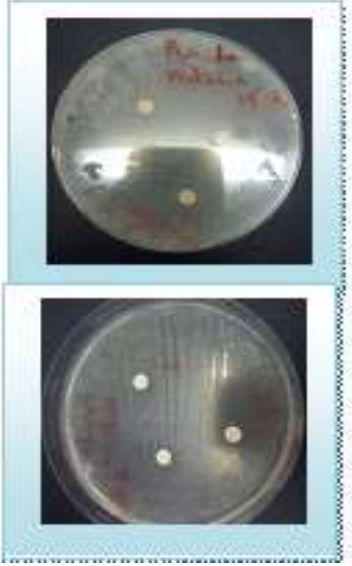

Figure 5: The effect of the methanolic extract on Pseudomonas aeruginosa

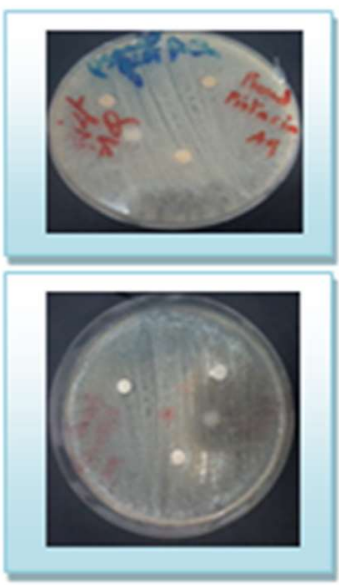

Figure 8: The effect of the aqueous extract on Pseudomonas aeruginosa.

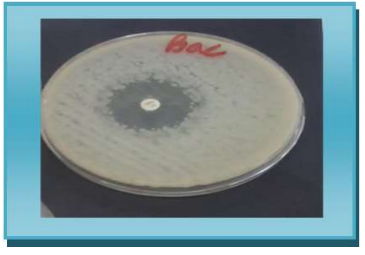

Figure11: The effect of gentamicin on Pseudomonas aeruginosa. 


\section{CONCLUSION}

Pistacia lentiscus L. leaves contain significant amounts of polyphenols and flavonoids with antibacterial activity, low antioxidant, and high anti-inflammatory activity. The

\section{REFERENCES}

Argolo ACC, SantAna A EG, Pletsch M and Coelho L CBB: 2004. Antioxidant activity of leaf extracts from Bauhinia monandra. Journal of Bioresources Technology. 95: 229- 233.

Johnson I T: 2001 Antioxidants and antitumor properties. Pages 100- 123 in J. Pokorny, N. Yanishlieva, M. Gordon (ed.), Antioxidants in Food, Woodhead Publishing Ltd., Cambridge.

Rietveld A \& Wiseman S: 2003. Antioxidant effects of tea: evidence from human clinical trials. The Journal of nutrition, 133(10), 3285S-3292S.

Serafini M Bugianesi R, Maiani G, Valtuen S, De Santis S, \& Crozier A: 2003. Plasma antioxidants from chocolate. Nature, 424(6952), 10131013.

Tan B L, Norhaizan M E, and Liew W P P: 2018: Nutrients and oxidative stress: friend or foe? Oxid. Med. Cell. Longev. , article ID 9719584, 24 pages.

Abbas G, Salman A, Rahman S U, Khalil Ateeq M, Usman M. Sajid S, Zaytoon, Tayyaba Y: 2017. Aging mechanisms: linking oxidative stress, obesity and inflammation. Matrix Sci. Medica 1, 3033.

Liu B, Wang J, Chan KM, Tjia WM, Deng W, Guan X, Huang JD, Li KM, Chau PY, Chen DJ, Pei D, Pendas AM, Cadiñanos J, López-Otín C, Tse HF, Hutchison C, Chen J, Cao Y, Cheah KS, Tryggvason K, Zhou Z: 2005. Genomic instability in laminopathy-based premature aging. Nature medicine, 11, 780-785.

Yoon JH, Baek SJ. 2005: Molecular targets of dietary polyphenols with anti- recommendation for future study is doing another study on the same plant using their fruits or doing the same study use other bacterial strains so as to get more results.

inflammatory properties.Yonsei medical journal, 46:585-596.

Winrow V R, Winyard P G, Morris C J, Blake $\mathrm{D} \quad \mathrm{R}:$ 1993. Free radicals in inflammation: second messengers and mediators of tissue destruction. British Medical Bulletin. ; 49:506-522.

Gutteridge J M. 1995: Lipid peroxidation and antioxidants as biomarkers of tissue damage. Clinical chemistry.; 41:1819_ 1828.

Menichini F, Tundis R, Bonesi M, Loizzo MR, Conforti F, Statti G, De Cindio, P J Houghton and F. Menichini : 2009. The influence of fruit ripening on the phytochemical content and biological activity of Capsicum chinense Jacq. cv Habanero. Food Chemistry. 114:553-560.

Mueller M, Hobiger S and Jungbauer A. 2010. Anti-inflammatory activity of extracts from fruits, herbs and spices. Food Chemistry ; 122:987-99

Bellakhder, J: 1997. La pharmacopée marocaine traditionnelle; Médicine arabe ancienne et savoir populaire. Ibis Press, Saint Etienne, p. 764.

Tohidi M, Khayami M, Nejati V, and Meftahizade H: 2011. "Evaluation of antibacterial activity and wound healing of Pistacia atlantica and Pistacia kbinjuk,", Journal of Medicinal Plant Research, vol. 5, no. 17, pp. 4310-4314,

Predrag. L, Hui S, Uri C, Hassan A, Arieh B: 2005. The effects of aqueous extracts prepared from the leaves of Pistacia lentiscus in experimental liver disease, Journal of Ethnopharmacology 100 198-204.

Lakić N., Mimica-Dukić N, Isak J, and Božin B: 2010. Antioxidant properties of Galium 
verum L. (Rubiaceae) extracts. Open Life Sciences, 5(3), 331-337.

Li WD, Wei C L, White P J, Beta T: 2007. High-amylose corn exhibits better antioxidant activity than typical and waxy genotypes. Journal of Agricultural and Food Chemistry, 55: 291-298.

Bahorun T, Gressier B, Trotin F, Brunete C, Dine T, Vasseur J, Gazin J C, Pinkas M, Luycky M, Gazin M : 1996. Oxigen species scavenging activity of phenolic extract from howthorn fresh plant organs and pharmaceutical preparation. Arzneim Forsch / Drug Res, 1-6.

Hanato T, Kagawa H, Yasuhara T, Okuda T: 1998. Two new flavonoids and other constituents in licorice root: Their relative astringency and radical scavenging effects. Chemical \& Pharmaceutical Bulletin, 36(6) 2090-2097.

Bettaie R I, Bourgou S, Debez I B S, Karoui I J, \& Sellami I H: 2011. K Msaada, F Limam, B Marzouk. Effects of extraction solvents and provenances on phenolic contents and antioxidant activities of Cuminutes (Cuminutes um cyminutes um L.) seeds. Food Bioprocess Techno, 1007.

Oyaizu M: 1986. Studies on products of browning reactions: antioxidative activities of products of browning reaction prepared from glucosamine, Japanese Journal of Nutrition, pp 307-315.

Huang S J, \& Mau J L: 2006. Antioxidant properties of methanolic extracts from Agaricus blazei with various doses of $\gamma$ - irradiation. LWT-Food Science and technology, 39(7), 707-716.

Seema C, Sharan S V, Srinivasa R B, Meena V, 2011. In vitro anti-inflammatory activity of Methanolic extract of Centella asiatica by HRBC Membrane stabilization. Rasayan journal of chemistry, 4 (2): 457-460.

NCCLS (National Committee for Clinical Laboratory Standards). 1999. Performance standards for antimicrobial susceptibility testing. Wayne Pa. 9th International Supplement, M100-S9.

NCCLS National Committee for Clinical Laboratory Standards). 1997. Performance standards for antimicrobial disk susceptibility test. Wayne Pa. 6th ed. Approved Standard, M2-A6.

Alves TMA., Silva AF., Brandão M., Grandi TSM., Smânia EFA., Smânia Jr A., Zani, CL., 2000. Biological screening of Brazilian medicinal plants. Memórias do Instituto Oswaldo Cruz, 95: 367-373.

Vaya J, Belinky PA and Aviram M: 1997. Antioxidant constituents from licorice roots: Isolation, structure elucidation and antioxidative capacity toward LDL oxidation. Free Radical Biology and Medicine. 23(2): 302-313.

FerradjI, A. 2011. Antioxidant and antiinflammatory activities of alcoholic and aqueous extracts of leaves and berries Pistacia lentiscus L. Doctoral thesis, University of Ferhat Abbas, Setif, pp. 21,52 